American Journal of Applied Sciences 9 (9): 1479-1490, 2012

ISSN 1546-9239

(C) 2012 Science Publication

\title{
The Effect Of E-Commerce on the Development of the Accounting Information Systems in the Islamic Banks
}

\author{
Khalil Mahmoud AL-Refaee \\ Department of Accounting, Al-Balqa Applied University, Amman, Jordan
}

\begin{abstract}
This research aims to study whether there is an effect of the use of e-commerce on accounting information systems. A questionnaire was designed and distributed to accountants, heads of accounting departments, financial managers in Islamic banks. Then analyzing the results of the questionnaire by using (SPSS), and other statistical methods through descriptive methods The results of the study showed that using e-commerce effects the design of AIS, it also concluded that using ecommerce provides appropriate accounting information about available substances at the right time, at a credible and stable degree for decision makers, in addition, using e-commerce deals with providing the necessary protection in getting access to information through a username and password to prevent unauthorized entrances, and following means for operation completion such as digital signatures. In general, there is a large impact on the usage of e-commerce on AIS. Some salient conclusions and suggestions for further studies are presented.
\end{abstract}

Key words: Accounting information systems, e-commerce, islamic bank

\section{INTRODUCTION}

The e-commerce has become a realistic fact that includes an international open market that is not constrained by any geographical borders, the increasing growth in using the internet as an intermediate to execute the operations of the e-commerce, also the increasing growth in the e-commerce in another new challenge to account for its operations within the mechanical accountings systems in firms under those continuous rapid changes in the information and as a result for this growth in the e-commerce in the internet, a number of the most important current problems in the e-commerce field and the methods to solve them are on the table, which deals with the necessity of making the needed legislative structure to secure and support development in the international market about executing the commercial exchange electronically.

The existence of the information system in the present time is mostly connected to the existence of the e-commerce considering the importance of the ecommerce in the information systems performance, so it is dutiful to the commercial firms to have all the knowledge in the latest developments in the accounting information systems and its mutual relations with the other various systems that effect on it. The researcher has chosen that this study should be about Islamic banks because of being a part of commercial banks which are considered the most important activities in the economic system wheel in every community, due to the fact that the returns of the economic activity in the community are as much as the banking contribution in the economic activity. Banks must have tough foundation in the globalization world and that can be done by developing the accounting information systems through the e-commerce.

Looking at what we have mentioned earlier the topic of the study will highlight the effect of the ecommerce in developing accounting information systems in the Islamic banks in Jordan.

The dilemma of the study: The dilemma of the study is in the following question.

Will the usage of the e-commerce affect the accounting information systems in the Jordanian Islamic banks?

You can derive the following from the previous question:

- Will the e-commerce affect the design of the accounting information system

- Will the e-commerce affect the inputs of the accounting system

- Will the e-commerce affect the processing operation in the accounting system

- Will the e-commerce affect the outputs of the accounting system

- Will the e-commerce affect the safety of accounting system information

- Will the e-commerce affect accounting information used in decision making in the Jordanian Islamic banks 
The objectives of the study: The study aims to:

- Learn how much the e-commerce affects the design of the accounting information systems

- Learn how much the e-commerce affects the inputs of the accounting system

- Learn how much the e-commerce affects the processing operations in the accounting system

- Learn how much do the e-commerce affect the outputs of the accounting system

- Learn how much the e-commerce affect the information safety in the accounting system in the Jordanian Islamic banks

- Learn how much does the e-commerce affect the accounting information used in decision making in the Jordanian Islamic banks

The importance of the study: This study was made to look in to the e-commerce and its effect on the accounting information system in the Islamic banks and this comes from the importance of the accounting information system and its great role in developing banks and its contribution banks growth more effectively through the value that this system adds to facilitate the banks mission and with the extension of the informational revolution and the technical, technological development the operations procedures have become more accurate and rapid on one hand and less cost and effort on the other hand which necessarily contributed to turn the traditional commerce system into the e-commerce system to fulfill the objective that we have mentioned earlier.

Earlier studies: Al-Helo (2000), "The Effect of Using Information Technology System on The Comprehensive Banking Services in The Jordanian Banks from The Perspective of The Banking Leaderships", an unpublished MA thesis, administrative sciences and economy college, Al- Albeet University,Jordan. "The Effect of Using Information Technology System on The Comprehensive Banking Services in The Jordanian Banks from The Perspective of The Banking Leaderships".

This study aimed to prove that the Islamic banks in Jordan will not be able to continue working or competing in the case of not using the technology of the computer and communication effectively in performing its various tasks, so this study has sought to present a picture about the reality of the communications and information systems used in the Jordanian banks by asking the strategic planning directors, marketing directors and information technology directors in those banks, the study summarized the following results:

- Investing in the communication, computer technology leads to decrease in costs
- Investing in communication, computer technology leads to an increase in the banks' profits and an increase in the numbers of depositors and also an up rise in the service level given to clients and present it properly

- Banks will not be able to continue its work and providing services to clients, unless it uses communication- information technology

KS (2002) "analyzing the effective factors on the efficiency, and competence of the accounting informational systems in the Jordanian commercial banks, "unpublished MA thesis) by the title of: "Analyzing the effective factors on the efficiency and competence of the accounting informational systems in the Jordanian commercial banks".

This study has aimed to explain how much the "environmental organizational, behavioral factors of the users of the information who use the computers and administrative decision making prototypes "on the efficiency and competence of accounting informational systems.

The study has summarized the following results:

- Environmental factors affect the efficiency and competence of the accounting informational systems in the commercial Jordanian banks

- Organizational factors affect the efficiency and competence of the accounting informational systems in the Islamic banks and this variable has been the least effective one of all

- Behavioral factors of the information users affect the efficiency and competence of the accounting informational systems used in the Islamic

- The computers' hardware and software used in banks, has the major and biggest effect on the efficiency and competence on the accounting informational systems in banks

- The efficiency and competence of the accounting informational systems used in the Islamic banks are usually affected by the administrative decision prototypes followed in the Islamic banks

Tawfeq (Abd Shareef Tawfeq: "The E-Commerce Effect on The Development of Accounting Informational Systems-Examinational Study by Applying It on The Banking Sector for Means to Pay as E-Money, and their sercices connected to the systems of the E-Bank) study by the title of "The E-Commerce Effect on The Development of Accounting Informational Systems-Examinational Study by Applying It on The Banking Sector for Means to Pay as E-Money and their services connected to the systems of the E-Ban".

The objectives of this study: 
- To learn theoretical aspect of the most important ecommerce systems on the accounting informational system

- To learn the features of the Islamic banks which use the e-commerce and it's most important effects on the development of the accounting informational systems

- To evaluate how much the Islamic banks follow the (ATM) services in the year of (2003), which the central bank orders regarding the e-banking operations and releasing ways to pay money electronically

- To suggest what is needed regarding accounting to develop the accounting informational systems, to comprehend the upcoming much anticipated extension

This study has come up with the result that: executing e-commerce is done through the systems of electronically exchanged data and the internet commerce systems.

\section{Study hypothesis:}

Major hypothesis: Using e-commerce doesn't influence accounting informational systems in Islamic Banks in Jordan.

First subsidiary hypothesis: Using e-commerce does not influence the design of accounting informational systems in Islamic banks in Jordan.

Second subsidiary hypothesis: Using e-commerce does not influence the portals of accounting informational systems in Islamic banks in Jordan.

Third subsidiary hypothesis: Using e-commerce does not influence the processing functions in accounting informational systems in Islamic banks in Jordan.

Fourth subsidiary hypothesis: Using e-commerce does not influence the outcome of accounting informational systems in Islamic banks in Jordan.

Fifth subsidiary hypothesis: Using e- commerce does not influence the accounting information used in taking decisions in Islamic banks in Jordan.

Sixth subsidiary hypothesis: Using e-commerce does not influence the data security in accounting informational systems in Islamic banks in Jordan.

Theoretical perspective:

First: accounting informational systems:

Accounting information: Management needs information that is appropriate .confidential and that is given to decision makers at the right time to guarantee taking the right decisions that depends on giving them the appropriate information, that's why the prosperity of a decision and increasing its effectiveness depend how successful is the information system is in giving sufficient integrated information to make it easier to take an administrative decision and we have to be able to distinguish between data and information and between the characteristics of accounting information.

Data: Data has been given a lot of definitions that we will mention some of them:

It's a group of facts that have been noticed and it is the raw material that we get the information from and it's also the input of the information systems (Kenneth, 2001).

Data is the numbers and figures that are unexplained and it is the numbers that we are asked to process using the system (Paul, 1992).

And we can also define Data as the raw material that we get from information after processing it and those come as letters or uneven numbers and can only be useful after processing and analyzing them.

Information: It can be defined as:

- It is the meaningful and valuable data that achieves a specific goal and it's a group of facts and defined recorded data where administrative decision can be made based on them, this data can be quantitative or not quantitative and there is a lot of quantitative forms that can be traded through information systems (Paul, 1992)

- It is that data that has been analyzed and processed to reflect the actual economic facts and events to helps decrease the user's ability to take the right decisions

We conclude that information is data that has been processed appropriately so it becomes useful and meaningful serving the needs of the users who are the graduates and entrants and most importantly the administration.

Qualitative characteristics of accounting information: Major characteristic:

Adequacy: The adequacy in the accounting information is considered to be from the most important characteristics that must be provided in the information and it means the compatibility with the needs of accounting information users, it also means the accounting information ability in influencing the administrative decisions and its ability to help users of accounting information to make more accurate predictions about future events that is appropriate in the 
accounting information which is an important characteristic whether these information is for internal use of the facility or for its external use, but it is more important for the internal use and that's because of the direct dependence on it in solving problems and taking the decisions that have to do with the problem itself.

And the American Accounting Association considered that for the accounting information to be adequate it must be related to a goal that we are asked to achieve, as the Financial Accounting Commission identified the subsidiary characteristics of the accounting information adequacy:

The appropriate time: The need for the accounting information is considered to be a current and immediate need especially that a lot of the information loses its importance very quickly as a result of major changes in the surrounding environmental conditions and the characteristic of the right time is a very important characteristic that should be provided in accounting information because there is no value for the information unless it reached it's user in the right time to enable him to make the right decision and for the time of the accounting information to be appropriate, it has to be prepared long enough before making the decision.

The ability to predict: Administrators take their decisions under the light of competition and when they are uncertain of the surrounding environment which is why accounting information must be provided to them that will help them predict sincerely and decrease the level of risk, as the predictive information contributes in preparing plans and future policy making.

Regressive feed-back: Which is the accounting information that the system produces to make sure that the predictions are right and to make comparisons between the effective implementation and the plans set for making the corrective decisions regarding the mistakes and correcting them.

Reliability: For the accounting information to be useful for its users it has to have enough and accepted amount of trust and the ability to depend on it as a measure of financial and economic events and actions that it represents and for these information to be reliable and credible, it must meet the following characteristics.

Honesty in the presentation information: Which means that the accounting information given sincerely about the financial events and facts representing it, where there is compatibility between the values and accounting numbers and their details along with the economic and financial events that are being measured.
Impartiality: Which means the objectivity of accounting information so that it is free of bias and there isn't a group that takes it's right over another's which increases the confidence of the user in accounting information and its accuracy and safety.

Verifiability: Which means that the information is verifiable if any qualified person checked the data or the records by the following similar measurement methods and reached a similar conclusion to some extent that is when they agree in their opinions about the incoming values in the financial lists.

Subsidiary characteristics: Financial accounting standards have identified the following subsidiary characteristics that need to be provided in accounting information.

Comparability: The use of accounting policies leads to differ in accounting information related to the facility causing difficulty in making sectional comparisons and analysis, whereas displaying the accounting data in a form that makes it comparable to the information whether to the level of the sector as a whole or to the internal sector of the company, achieve greater ability to assess performance, improve predictions and the rationalization of administrative decisions.

Stability and coherence: Stability and coherence principle is very important in achieving the quality of comparability as it refers to the importance of the facility's commitment in applying the same policies in its dealings and activities through accounting consecutive sessions and the international accounting standards for companies to disclose the need for any changes in the accounting policies that are followed and to clarify the reasons that called for this change and its effects.

Accounting information systems: Accounting information systems is one of the subsystems in the economic unity and it consists of several subsystems functioning together in a coherent and mutual consistent way to provide information to all parties interested in economic unity, that they all aim to serve the economic unity within its overall objective.

Or it is one of the components of an administrative organization that is specialized in collecting, tabulating, processing, analyzing and delivering of the appropriate information for decision-making to outside parties.

And the accounting information system is considered to be one of the administrative information system's components and the difference between them is limited in that the first in specialized in data and accounting information while the second is specialized in all the data and information that affect the activity of the institution. 
Accounting information systems components: The accounting information system is like any other system that consists of a group of components to achieve its objective that it was established for and from these components:

- Evidentiary papers and documents that support the financial transactions that happen in the economical facility

- Data bases that stores the financial data for the accounting transactions

- Computer application that process the data to turn it into useful appropriate information

- Accounting procedures that are written and drawn for the sequence of financial operations in the facility

- Individuals that deal with one or more of the accounting systems

- $\quad$ Electronic means and communications technology in the accounting information systems

And the factors that affect accounting information systems lie in the individuals responsible of these systems and the function of collecting data, processing it, storing it and decision-making, in addition to the devices and used means to achieve the aim of accounting information systems in getting the accounting information supporting those decisions.

Accounting information systems features: In order for the accounting information system to be functional it has to have specific features which qualify it to be effective and they are (Al-Rawi, 2009):

- It has to be highly accurate and has ability to process the financial data rapidly when transformed into accounting information

- It has to provide the functional performance with the needed accounting information in the appropriate time to come up with a decision to chose an alternative from the available alternatives of the administration

- It has to provide the administration with the needed information to achieve the supervision and assessment to the facilities' economical activities

- It has to provide the administration with the needed information to help it with achieving its vital task which is short-term, medium-term and long-term planning for the facilities future business

- The accounting information system has to be fast and accurate in recollecting the quantitative description information stores in its data base when needed
The design pillars of the accounting information systems: There are many aspects that represent the pillars of any accounting system that the systems analysts and designers should know in order to guarantee designing and effective accounting information systems, which are:

- The cycle of preparing data in the accounting information system

- The objectives if the accounting information systems

- The environment of the accounting information systems

- The network of the accounting information systems

Tasks of the accounting information systems:

The accounting information systems fulfill the following tasks:

- Collecting and storing data concerned with the facilities activities and operations, efficiently

- Processing data by sorting, classifying and summarizing them....

- Generating useful information for decision making and provide the users with it

- Achieving the principle of supervision

Second: E-commerce:

The definition of E-commerce: The E-commerce is defined to be as the commercial transactions done by individuals and organizations that depend on processing and transporting digital data, including visual and audile ones..., through open networks, or closed networks that allow the users to have the access to open networks.

It is also defined as the usage of electronic means to enable the electronic commercial transactions including selling and buying the products and the services that require transferring them digitally or materially from one place to another.

In other words, the international market enable all the users and workers in the productive circles to cooperate instantly through an open market that is basically a platform for the comprehensive administration for the informational and scientific human relationships.

The association of control and audit of the Ecommerce information systems is defined as the processes on which the facilities conduct E-business with clients, suppliers or people who use the internet as a technique that enables them to do so.

Types of E-commerce: E-commerce is divided into four kinds of transactions based on the nature of dealers:

Business-business (facilities) E-commerce: Deals which include (purchase orders, receiving of vouchers 
and payments) that are done between business facilities, using communication and information technology networks, this type of the e-commerce is the most used one and represents the major percentage.

Business facility-consumer E-commerce: Which is also called E-shopping or retail E-commerce because the deal done directly with a consumer, where the facility exposes it's products to hypothetical E-stores on the web and then promotes them then conduct deals with the consumers, this type of E-commerce is the least used one but it is growing practically.

Business facility-government E-commerce: This type of E-commerce represents the governments relationships with the business firms, where governmental purchases and deals are done through the internet also where governmental purchases and deals are done through the internet also where the government display its products or services needed and the required standards through the internet for firms to present its E-displays and then the government could chose the appropriate display which corresponds to it's descriptions and you can use this type of E-commerce to settle the corporate taxes for instance.

This type of E-commerce is still considered to be in its early stages but it is expected to expand when the governments adopt this idea and use it to conduct deals with corporations.

Consumer-government E-commerce: This type of Ecommerce will expand after the expansion of other types of E-commerce, through this type of e-commerce the citizen can conduct and finish his governmental official papers through the internet like paying taxes, paying traffic tickets.

Another type of e-commerce has emerged which is known as cell phones e-commerce, this type of ecommerce is considered to be the latest type of ecommerce done by cell-phone designed to connect to the internet by a service supplier and get access to any specific website and take a look at items for sale and conduct the purchase operations.

The significance of E-commerce: We can say that Ecommerce is one of the most significant inventions of our time and one can make profits using just as the profits one could achieve using the old traditional ways, due to the following reasons:

- The low cost: promoting a product in the past used to cost a lot, due to the fact that the promotion of a product used to be through traditional means such as television and newspapers, but now you can promote the same products using the internet with a very low cost

- Going beyond local borders: the facility used to deal with local clients only and if this facility wanted to approach international clients, it had had to bear with great expenditures and the returns of those international deals were not completely guaranteed, but nowadays the facility can make sure that everyone can navigate through its pages online and could take a look at what the facility promotes with paying any mentionable expenditures, due to the fact that internet is everywhere in every country

- Breaking the chains: facilities needed to get certain authorization, abide by many regulations, having to bear the costs of establishing new branches, or hire other people in foreign so it could sell its products, but none of these procedures are necessary

Technical needs of the E-commerce: The technical needs of the E-commerce infrastructure can be divided into the following:

- Devices, including: computers, cables and high techniques for communications

- Software, including: operating software and navigation software, in addition to E-commerce software bundles.

- Internet service providers

- Authorized services: services concerned with conducting commercial deals, such as advertisements, payment means, delivery and to verifying the qualifications of the services

- Supportive legal pillars and the cultural activities of the E-commerce

E-commerce-Accounting science bond: Accounting and auditing assemblies are very concerned with Ecommerce due to the fact that selling operations done but the facilities website connected directly to the automated accounting information systems and it has become inevitable for the accountant and the auditor to learn this new science, Marcella (1998) wrote in his article "The effectiveness of E-commerce" in "Informational Technology Audit" magazine: “ Ecommerce has made great changes in the universal trade science and the mechanisms of the commercial operations which made it necessary to the accountant and the auditor to comprehend those changes and their effect to the business they do and the legal environmental circumstances concerned with the business.

It is important to mention that E-commerce and the internet could contribute to the quantitative information features by providing the adequacy feature greatly 
especially by providing the subsidiary feature of the appropriate timing, researchers think that the accounting information system is useless if those information were not authenticated when used to providing important information for stakeholders in general and for the decision maker in particular and since the E-commerce system related to the internet ids directly connected to the automated accounting information system, the outputs of the accounting information system are not reliable in the case when something goes wrong, or in the case of hacking to that accounting information system hence the consumers will no longer trust that system.

As a conclusion, if one want the information of that accounting system to be highly authenticated two significant things must be taken into consideration, the first one is to find a specific mechanism to protect the accounting information system from being hacked through the internet, the second one is to find a specific mechanism to insure the security of the E-commerce technique and the facility's navigation websites through the internet.

The requirements of accounting information systems: Accounting information systems must have essential requirements in order to make the e-commerce work sufficiently and efficiently, these requirements are:

- Integrated Information

- The ability to achieve the exchange of information and services between the various information systems and the corporations and assemblies involved in the process

- Conducting the previously mentioned exchange in an appropriate time for each party involved

- Involving the biggest number of users from various parts of the world till the process becomes to what is known as the competence market condition at the end

Threats facing accounting information systems used in E-commerce: The accurate comprehensive information is like the spinal vertebral for any economical unit that has the desire to continue to grow, because those information are like the foundation pillars that the administration builds it's decision regarding any problems or situations the corporations might face. There is no doubt that having an excellent and appropriate accounting information system is one of the most essential factors they could define the success of failure in achieving the objectives with high competence and efficiency.

That's why all facilities plan to have sufficient accounting information systems that use modernized computers because the information technology based on computers has become the primary mean to transport, exchange, process data within most facilities and companies regardless of their business, this has led to discover the importance of the information and data safety considering it one of the most essential elements of accounting systems. On the other hand this amazing development in the field of e-commerce indicates to the necessity of enhancing accounting information systems in order to suit the e-commerce it also indicates the necessity to learn the most important demands of the interior supervision of the information safety.

And here are the most major threats that any computer-based accounting information system could face and also might be affected by the work environment in e-commerce:

- Hacking into the accounting information systems by interior parties who don't have access to the system or by exterior parties (hackers) by stealing the system's passwords

- This hacking may lead to distort the data of the accounting information system consequently leading to making bad decisions

- Hacking into systems might lead to stealing highly confidential important information that one might benefit financially

- This hacking might also lead to insert viruses to the accounting information system that might distort and damage some of the information or files or programs or operating systems or all of them, consequently discharge the informational content of the system

- Obstruction might occur in the function of the accounting information system, by overloading it with data exchange requests, which might obstruct the users from getting access and this loss in connectivity will miss real active chances for the facility

- The incompetence of the interior users might lead to installing incorrect data or subtracting data by mistake, some say that this type of threat is a big source for financial losses related to the accounting information system

- Using inappropriate, modified programs usually leads to operating data wrongly, hence getting false results

\section{Data analysis and testing hypothesis:}

The study methodology: The study relied on the descriptive and analytical approach, where secondary and primary data are gathered to achieve the purposes of the study,

The means to gather data: Secondary data: it includes the theoretical aspect of the study, by going back to the Arabic references and other foreign studies to cover the whole theoretical aspect.

Primary data: The primary needed data has been obtained to test the hypothesis. The researchers have 
made a questionnaire to achieve the objectives of the study and this questionnaire has covered each and every hypothesis of the study, they have also tested the hypotheses by using the statistical program (SPSS).

The study equipment: The study relied on a questionnaire that has been designed by going back to the theoretical aspect and other previous studies about the effect of the e-commerce on the development of the accounting information systems in the Jordanian Islamic banks; this questionnaire is divided into two parts:

The first part: The aim of this part is to learn the demographic features of the individuals who answered the questionnaire and included the following features (age, gender, career, qualifications, specialty and experience).

The second part: It consists of 47 articles distributed to 6 major groups, in order to measure the fields, the hypotheses of the study deal with.

The statistical means used in the study: They have relied on the statistical bundle (SPSS) to analyze data, they have also relied on the standard deviation and the arithmetic mean, to analyze the answers of the individuals who took the questionnaire, as well as relying on the test (T) to examine the hypotheses of the study. Credibility factor (alpha-kronbakh) has been used to measure the credibility of the answers in the questionnaire.

The tested sample: The study has included the three Jordanian Islamic banks, which are: Islamic bank, the Arab Islamic, Islamic bank of Dubai, the sample of the study included the employees of the accounting departments, the chiefs of the accounting departments, the interior auditors, financial chiefs who deal with accounting information systems in banks.

32 questionnaires have been distributed and 26 of the ones distributed were returned which equals a percentage of $(81.25 \%)$ which is considered to be an acceptable, good percentage.

The study sample features: The questionnaire has been distributed to the employees of the accounting departments, the auditors and the financial chiefs in the Jordanian Islamic banks being the most capable ones to answer the questionnaire.

First: The study sample according to the age: Looking at Table 1, you can notice that $42 \%$ of the tested sample are between the

Second: The study sample according to the gender: Looking at Table 2, you can notice that the percentage of the males in the study was about $58 \%$ and the percentage of the females was about $42 \%$.
Third: The study sample according to the occupational level: Looking at Table 3, you can notice that the percentage of the financial managers is $11.5 \%$ the percentage of the heads of the accounting department is $15 \%$

As for the accountants the percentage is $62 \%$ and the interior auditor percentage is $11.5 \%$

Forth: The study sample according to qualification: Looking at Table 4, we notice that the percentage of those who have a BA degree is around 69\% MA degree percentage is around $19 \%$ and the percentage of those who have $\mathrm{PH}$ degree is $11.5 \%$

Fifth: The study sample according to the specialty: Looking at Table 5, we can notice that most individuals have a BA degree in the, accounting major which forms a percentage of around $54 \%$ of the tested sample while the percentage of those who have a B.A degree in business management reached the percentage of $23 \%$ as those who have a B.A degree in banking and financial sciences their percentage was around $11.5 \%$

\begin{tabular}{lcr}
\multicolumn{3}{l}{ Table 1: Classifying the individuals of the study according to their ages } \\
\hline Age & Frequency & Percentage \\
\hline 30 years or less & 3 & 11.50 \\
31-less than 40 & 11 & 42.30 \\
40-less than 50 & 9 & 34.60 \\
50-less than 60 & 3 & 11.50 \\
Total & 26 & 100.00 \\
\hline
\end{tabular}

Table 2: Classifying the individuals of the study according to the gender

\begin{tabular}{llr}
\hline Gender & Frequency & Percentage \\
\hline Male & 15 & 57.70 \\
Female & 11 & 42.30 \\
Total & 26 & 100.00 \\
\hline
\end{tabular}

Table 3: Classifying the individuals according to their occupational level

\begin{tabular}{lcr}
\hline Occupational level & Frequency & Percentage \\
\hline Financial manager & 3 & 11.50 \\
The head of the & 4 & 15.40 \\
accounting department & & \\
Accountant & 16 & 61.50 \\
Financial auditor & 3 & 11.50 \\
Total & 26 & 100.00 \\
\hline
\end{tabular}

Table 4: Classifying the individuals of the study according to qualification

\begin{tabular}{lcc}
\hline Qualification & Frequency & Percentage \\
\hline BA degree & 18 & 69.20 \\
MA degree & 5 & 19.20 \\
PH degree & 3 & 11.50 \\
Total & 26 & 100.00 \\
\hline
\end{tabular}

Table 5: Classifying the individuals of the study according to their specialty

\begin{tabular}{lcc}
\hline Specialty & Frequency & Percentage \\
\hline Business management & 6 & 23.10 \\
Accounting & 14 & 53.80 \\
Economic & 3 & 11.50 \\
Banking and financial sciences & 3 & 11.50 \\
Total & 26 & 100.00 \\
\hline
\end{tabular}


Sixth: The tested sample according to their experiences: Looking at Table 6 most of the individuals of the sample have an experience between (3-less than 6 years) with a percentage of around $50 \%$.

Study results display: The arithmetic mean and the standard deviation to describe the sample have been calculated in the following paragraphs:

Looking back at the schedule you can see the positive value of the mentioned paragraphs because the arithmetic mean is about the measure average tool
(3). It noticed that from Table 7 that the value of the trends are positive towards the paragraphs above. Since their averages are larger than the third measurement tool.

Table 6: Classifying the individuals according to their experiences

\begin{tabular}{lcr}
\hline Years of experiences & Frequency & Percentage \\
\hline Less than 3 years & 4 & 15.40 \\
Between 3- less than 6 years & 13 & 50.00 \\
Between 6- less than 10 years & 7 & 26.90 \\
10 years or more & 2 & 7.70 \\
Total & 26 & 100.00 \\
\hline
\end{tabular}

Table 7: "Study results display

\begin{tabular}{|c|c|c|}
\hline Paragraphs & $\begin{array}{l}\text { Arithmetic } \\
\text { mean }\end{array}$ & $\begin{array}{c}\text { Standard } \\
\text { deviation }\end{array}$ \\
\hline The surrounding & 4.35 & 0.56 \\
\hline $\begin{array}{l}\text { Environment imposes the decision makers in the bank designing } \\
\text { accounting information systems that saves the costumers electronic documents } \\
\text { The design of the Accounting information systems is }\end{array}$ & & \\
\hline effected by the technological development in the field of the e- commerce & 4.5 & 0.71 \\
\hline Providing customers with suitable high level e- commerce services & & \\
\hline affect the design of the accounting information systems & 4.73 & 0.53 \\
\hline $\begin{array}{l}\text { Accounting information systems that achieve flexibility to the bank are designed to } \\
\text { provide e- commerce services }\end{array}$ & 4.19 & 0.69 \\
\hline $\begin{array}{l}\text { The design of the accounting information systems is affected by } \\
\text { the strong competition between accounting banks }\end{array}$ & 4.38 & 0.50 \\
\hline The design of the accounting information system is affected with other subsidiary systems & 4.58 & 0.50 \\
\hline $\begin{array}{l}\text { When designing an accounting information system the governmental } \\
\text { regulations should be taken in consideration }\end{array}$ & 4.12 & 0.91 \\
\hline $\begin{array}{l}\text { When designing accounting information systems costs and } \\
\text { returns should be taken in consideration }\end{array}$ & 4.12 & 0.77 \\
\hline $\begin{array}{l}\text { The design of the accounting information Systems should be frequently } \\
\text { revised to apply the governmental laws and regulations }\end{array}$ & 4.46 & 0.65 \\
\hline Using e- commerce facilitates obtaining accounting data & 3.96 & 0.77 \\
\hline Using e- commerce completely provides the needed accounting & 4.96 & 0.47 \\
\hline Using e- commerce provides the needed data in the appropriate time & 4.19 & 1.36 \\
\hline Using e- commerce decreases the cost of obtaining the accounting data & 3.96 & 1.11 \\
\hline Using e- commerce provides accounting data that is valid for the accounting measure & 4.31 & 0.79 \\
\hline Using e- commerce provides data that reflects reality & 4.31 & 62.00 \\
\hline Using e- commerce fastens the operation of processing financial data & 4.46 & 0.51 \\
\hline Using e- commerce processes the financial data accurately & 4.77 & 0.43 \\
\hline Using e- commerce decreases the mistakes in processing financial data & 4.58 & 1.14 \\
\hline Using e- commerce decreases the cost of Exchanging financial data & 3.77 & 1.14 \\
\hline Using e- commerce fastens the process of restoring stored information & 4.27 & 0.69 \\
\hline Using e- commerce restores stored data accurately & 4.31 & 97.00 \\
\hline Using e- commerce provides accounting information in the appropriate time for the decision makers & 4.38 & 0.57 \\
\hline Using e- commerce provides totally accurate information & 4.04 & 0.77 \\
\hline Using e- commerce provides appropriate accounting information for the decision makers & 4.04 & 0.82 \\
\hline $\begin{array}{l}\text { Using e- commerce provides accounting information based on primary data supported } \\
\text { with documents or objective facts }\end{array}$ & 4.35 & 0.85 \\
\hline Using e- commerce provides information has the ability to be compared & 4.31 & 0.97 \\
\hline Using e- commerce provides authenticated information & 4.96 & 0.47 \\
\hline Using e- commerce provides reports when they are needed & 4.19 & 0.69 \\
\hline Using e- commerce provides credible information & 4.04 & 0.82 \\
\hline Information concerning clients' needs is provided in a way that suites the decision makers & 4.35 & 0.85 \\
\hline Information about client satisfaction is provided concerning the provided services & 4.31 & 0.97 \\
\hline Needed information about available alternatives is provided & 4.65 & 0.49 \\
\hline Using e- commerce facilitates the process of observation in the various sectors & 4.42 & 0.58 \\
\hline Information about costs and services that the bank provides is provided & 4.19 & 0.69 \\
\hline Accounting information systems provide suitable information for making investment decisions & 4.58 & 0.64 \\
\hline $\begin{array}{l}\text { There is a record about the failed attempts of hacking into the } \\
\text { accounting information systems by exterior affairs }\end{array}$ & 4.42 & 0.58 \\
\hline There is a follow up to those failed hacking attempts that reveal their source and reasons & 4.23 & 0.71 \\
\hline $\begin{array}{l}\text { There are security measures to ban interior hacking attempts } \\
\text { by parties who don't have access into the system }\end{array}$ & 4.35 & 0.56 \\
\hline Control means to get access to data are being used. like using user names .and passwords & 4.46 & 0.81 \\
\hline Control means are used to close deals through the internet like using digital prediction & 4.38 & 0.57 \\
\hline The date existed in the accounting information systems is coded & 4.04 & 0.72 \\
\hline There is a mechanism to protect the banks website from viruses & 4.19 & 0.75 \\
\hline
\end{tabular}


Table 8: The test results of the first hypotheses

\begin{tabular}{llll}
\hline Calculates T & Scheduled T & SIG & Hypotheses \\
\hline 14.103 & 2.0595 & 0.001 & $\begin{array}{l}\text { Result } \\
\text { Refusal }\end{array}$ \\
\hline
\end{tabular}

Table 9: The test results of the second hypothese

\begin{tabular}{llll}
\hline Calculated T & Scheduled T & SIG & HO result \\
\hline 9.732 & 2.0595 & 0.001 & refusal \\
\hline
\end{tabular}

Table 10: The test results of the third hypotheses

\begin{tabular}{llll}
\hline Calculated T & Scheduled T & SIG & HO result \\
\hline 12.313 & 2.0595 & 0.001 & refusal \\
\hline
\end{tabular}

Table 11: The test results of the forth hypotheses

\begin{tabular}{llll}
\hline Calculated T & Scheduled T & SIG & HO result \\
\hline 11.945 & 2.0595 & 0.001 & refusal
\end{tabular}

Table 12: The test results of the fifth hypotheses

\begin{tabular}{llll}
\hline Calculated T & Scheduled T & SIG & HO result \\
\hline 14.357 & 2.0595 & 0.001 & refusal \\
\hline
\end{tabular}

Table 13: The test results of the sixth hypotheses

\begin{tabular}{llll}
\hline Calculated T & Scheduled T & SIG & HO result \\
\hline 14.088 & 2.0595 & 0.001 & refusal \\
\hline
\end{tabular}

The first hypothesis Table 8:

HO: Using e-commerce does not affect the design of the accounting information systems in the Jordanian Islamic banks.

HA: Using e-commerce affects the design of the accounting information systems in the Jordanian Islamic banks.

ONE SAMPLE T-TEST has been used and by looking at the previous computer results in the schedule we can notice that the value of the (CALCULATED T equals: 14.103 is bigger than its scheduled value and since the decision is made based on: accepts $\mathrm{HO}$ if the calculated value is less than the scheduled value hence we refuse the $\mathrm{HO}$ and accept the alternative hypotheses HA. This means that using e-commerce affects the design of the accounting information systems in the Jordanian Islamic banks.

\section{The second hypotheses Table 9:}

HO: Using e-commerce does not affect the inputs of the accounting information systems in the Jordanian Islamic banks.

HA: Using e-commerce affects the inputs of the accounting information systems in the Jordanian Islamic banks.

ONE SAMPLE-TEST, has been used and by looking at the previous computer results in the schedule, we can notice that the value of the (CALCULATED T) equals: 14.103, is bigger than its scheduled value and since the decision is made based on: accepts HO if the calculated value is less than the scheduled value and refuses the HO if the calculated value is bigger than the scheduled value, hence we refuse the $\mathrm{HO}$ and accept the alternative hypotheses HA. This means that using e-commerce affects the process operations of the accounting information systems in the Jordanian Islamic banks

\section{The third hypotheses Table 10:}

HO: using e-commerce does not affect on the process operation in the accounting information systems in the Jordanian Islamic banks.

HA: using e-commerce affects the process operations in the accounting information system in the Jordanian Islamic banks.

ONE SAMPLE-TEST, has been used and by looking at the previous computer results in the schedule, we can notice that the value of the (CALCULATED T) equals: 12.313 is bigger than its scheduled value and since the decision is made based on: accepts HO if the calculated value is less than the scheduled value and refuses the $\mathrm{HO}$ if the calculated value is bigger than the scheduled value, hence we refuse the $\mathrm{HO}$ and accept the alternative hypotheses HA. This means that using e-commerce affects the process operations of the accounting information systems in the Jordanian Islamic banks.

The forth hypotheses Table 11:

HO: Using e-commerce does not affect the outputs of the accounting information systems in the Jordanian Islamic banks.

HA: Using e-commerce affects the outputs of the accounting information systems in the Jordanian Islamic banks.

ONE SAMPLE T- TEST, has been used by looking at the previous computer results in the schedule, we can notice that the value of the (CALCULATED T) equals: 11.945 , is bigger than its scheduled value and since the decision is made based on: accepts HO if the calculated value is less than the scheduled value and refuses the $\mathrm{HO}$ if the calculated value is bigger than the scheduled value, hence we refuse the $\mathrm{HO}$ and accept the alternative hypotheses HA. This means that using ecommerce affects the outputs of the accounting information systems in the Jordanian Islamic banks.

The fifth hypotheses Table 12:

HO: Using e-commerce does not affect the accounting information used in making decisions in the Jordanian Islamic banks. 
HA: using e-commerce affects the accounting information used in making decisions in the Jordanian Islamic banks.

ONE SAMPLE T-TEST, has been used and by looking at the previous computer results in the schedule, we can notice that the value of the (CALCULATED T) equals: 14.357, is bigger than its scheduled value and since the decision is made based on: accepts HO if the calculated value is less than the scheduled value and refuses the $\mathrm{HO}$ if the calculated value is bigger than the scheduled value, hence we refuse the $\mathrm{HO}$ and accept the alternative hypotheses HA. This means that using e-commerce affects the accounting information used in making decisions in the Jordanian Islamic banks.

\section{The Sixth hypotheses Table 13:}

HO: Using e-commerce does not affect the safety of the information in the accounting information system in the Jordanian Islamic banks.

HA: Using e-commerce affects the safety of the information in the accounting information systems in the Jordanian Islamic banks.

ONE SAMPLE T-TEST, has been used and by looking at the previous computer results in the schedule, we can notice that the value of the (CALCULATED T) equals: 14.088, is bigger than its scheduled value and since the decision is made based on: accepts HO if the calculated value is less than the scheduled value and refuses the $\mathrm{HO}$ if the calculated value is bigger than the scheduled value, hence we refuse the $\mathrm{HO}$ and accept the alternative hypotheses HA. This means that using e-commerce affects the safety of the information in the accounting information systems in the Jordanian Islamic banks.

\section{Results:}

The study has concluded the following results: The design of the accounting information systems is greatly affected by the technical and information technology development, in the field of e-commerce and that we should keep up with this development, consequently there must be continuous change in the design of accounting information systems in the Jordanian Islamic banks.

The inputs of the accounting information system are so easy after using e-commerce, this leads to restoring it easily and being described with the feature of the appropriate timing, regarding the time we need in installing and restoring it again, these inputs are also authenticated, this feature is very important in the banking field. Using e-commerce has reduced errors greatly, in the process of accounting data input and the credit goes back to the interior auditing and surveillance system. We do not miss that the data cost was less than its benefit, but when the e-commerce emerged the cost of this data is very little, this means that there is a positive effect between using e-commerce and the inputs of the accounting information systems in the Islamic banks.

Using e-commerce provided accurate, flawless and fast financial data processing, which is the second stage in any systems and it has decreased the number of employees working on closing deals and also decreased the cost of financial data and information and increased the speed and accuracy in restoring stored information.

E-commerce has a positive effect on the output of the accounting systems in the Jordanian Islamic banks, because the e-commerce provides accurate and comprehensive accounting information on one hand and authenticated accounting information on the other hand. This accounting information is measurable and it is instantly sent to the decision makers in the right time.

Using e-commerce in the Islamic banks, leads to using security means to control data, like "user name and password", as well as using ways to control closing deal through the internet such as "digital signature".

Using e-commerce in the Islamic banks provides accounting information for the decision makers through giving sufficient, complete information regarding the available alternatives, as well as providing information regarding clients' satisfaction about the provided services in the Islamic banks, in addition to providing information about clients' needs.

\section{Recommendations:}

- Islamic banks must develop accounting information systems continuously, in order to keep up with the development, so it would adopt with the technological and technical demands of our generation

- Islamic banks should follow up with everything new and moderns, in order to meet the client's needs and desires

- Islamic banks should keep up with new information regarding accounting sciences and keep up with the international standards in the accounting field, so it would work in a consolidated and acceptable system, in order to keep up with the scientific development in this field

- Islamic banks must continue developing a monitoring system in the accounting information system in the field of e-commerce, to limit the hacking attempts which are getting stronger by time 
- Islamic banks must use automated systems instead of manual systems in the time of globalization in order to keep up with the development

- Islamic banks should be more concerned with scientific research in order to learn new things, to upgrade the level of performance

- More researches must be conducted about the development of accounting information system, when using e-commerce and focus to develop it continuously

\section{REFERENCES}

Al-Helo, B., 2000. Effect of Using Information Technology System on The Comprehensive Banking Services in The Jordanian Banks from The Perspective of The Banking Leaderships. M.Sc Thesis, ALalbeet University, Jordan.
Al-Rawi, H., 2009. Accounting information systems and the organization. Culture Library for Publishing and Distribution, Jordan.

Kenneth, 2001. E-Commerce by Eyewire.

KS, 2002. analyzing the effective factors on the efficiency, and competence of the accounting informational systems in the Jordanian commercial banks. MS.c Thesis.

Marcella, A., 1998. Electronic commerce.

Paul, S., 1992. Reynolds, information systems for managers. West Publishing Company. 